\title{
Enamel-renal syndrome
}

INSERM

\section{Source}

INSERM. (1999). Orphanet: an online rare disease and orphan drug data base. Enamelrenal syndrome. ORPHA:1031

Amelogenesis imperfecta-nephrocalcinosis, also called enamel-renal syndrome, is an extremely rare syndrome which is characterized by hypoplastic amelogenesis imperfecta (hypoplastic dental enamel) and nephrocalcinosis (precipitation of calcium salts in renal tissue). Oral manifestations include yellow and misshaped teeth, delayed tooth eruption, and intrapulpal calcifications. Nephrocalcinosis is often asymptomatic but can progress during late childhood or early adulthood to impaired renal function (e.g. recurrent urinary infections and renal tubular acidosis), and rarely to end-stage renal failure. 